\title{
RESEARCH ON THE EFFECTS OF READING HABITS ON THE ACADEMIC ACHIEVEMENT OF HIGH SCHOOL STUDENTS IN BIOLOGY COURSE
}

\author{
Arzu Önel ${ }^{1}$, \\ Şule Firat Durdukoca ${ }^{2 i}$ \\ ${ }^{1}$ Assoc. Prof. Dr., \\ Kafkas University, \\ Faculty of Education, \\ Department of Biology Education, \\ Kars, Turkey \\ orcid.org/0000-0003-4205-3939 \\ ${ }^{2}$ Assoc. Prof. Dr., \\ Kafkas University, \\ Faculty of Education, \\ Department of Special Educational, \\ Kars, Turkey \\ orcid.org/0000-0001-8864-3243
}

\begin{abstract}
:
The aim of this study is to examine whether reading habits have any effects on the academic achievement of the biology course of high school students in Turkey. In the research, the relational screening model was preferred from the quantitative research models and the phenomenological approach was preferred from the qualitative research models, so the mixed method was used. The study group consists of 266 students studying in the final year of various high schools and who took biology courses before in the province of Kars in Turkey. Data were collected by the questionnaire form prepared by the researchers. In the questionnaire, the participants were asked 12 questions in total; 4 questions to determine the variables of the type of school, education fields, gender, school report marks, 5 close-ended questions to be thought to be able to determine their reading habits, 2 open-ended questions and 1 metaphor question. Frequency and percentage values were calculated for descriptive analysis of the answers given to the questionnaire items. Chi-square analysis was used to examine the relationship between demographic characteristics and the reading habits of the students, and the content analysis technique was used to analyze metaphors.
\end{abstract}

Keywords: academic achievement, biology course, book reading, high school

i Correspondence: email arzuonel@gmail.com $\underline{\text { drsulefirat@gmail.com }}$ 


\section{Introduction}

Reading is a process of communication, perception, learning, and development (Güngör, 2009) and it gives the individual many skills beyond visible in this process. So much so that reading enables the individual to develop and progress in all areas, primarily cognitive and verbal development, improves vocabulary, eliminates inequalities in success (Cunnington and Stanovich, 2003). Reading improves comprehension, enriches knowledge (Devrimci, 1993). Reading gives skills to look at life from different perspectives, to speak properly and beautifully. Reading contributes to the development of the individual in mental, emotional and social aspects (Aktaş and Gündüz, 2005). As reading develops mental skills, it gives the ability to understand events in a multifaceted way, interpreting, criticizing, analyzing, synthesizing and evaluating, thus the ability to interrelate logically (Batur and Bek, 2010). Even students with limited comprehension skills can improve their vocabulary and thinking skills through reading.

Reading is the basis of learning (Keçik and Uzun, 2002). The higher the level of reading, the higher the level of learning (Issa et al., 2012). The formation of reading habits depends on enjoying it and doing it over and over again just like swimming, playing tennis and basketball (Özdemir, 1990). For the individual to have this habit is only possible if $s /$ he continues the reading activity constantly and regularly in every part of his/her life (Güngör, 2009).

Reading occurs through understanding the message to be given correctly (Özdemir, 1990). As the student who has acquired this skill will be able to receive the message to be given correctly in all courses, his/her academic achievement will increase. Whichever the type and whatever the purpose, a positive attitude to reading is the key to success, because the achievement in courses depends on understanding the majority of the words in texts and the general essence of the messages conveyed (Reed, Petscher and Truckenmiller, 2017). Many literature findings exist as to reading increases academic achievement (Gallik, 1999; Marks, McMillan and Hilman, 2001; Cunnington and Stanovich, 2003; Tatar and Soylu, 2006; Aksaçlığlu and Yılmaz, 2007; Acıyan, 2008; Sallabaş, 2008; Güngör, 2009; Adalı, 2010; Y1lmaz and Okur, 2010; Y1lmaz, 2012; Gül, 2013; Yıldız, 2013; Güney et al., 2014; Akın, 2016).

One of the references to bring the relationship between reading skills and academic achievement to light is PISA 2015 data. The Programme for International Student Assessment (PISA) conducted by The Organization of Economic Cooperation and Development (OECD) of which Turkey is also among the founders is one of the most comprehensive researches conducted at an international level in the field of education. PISA conducts its researches on the $7^{\text {th }}$ grade and higher grade students enrolled in formal education aged 15. As PISA does not make an assessment in the subject of biology, science literacy which is the top science of biology and reading skills are taken as reference. According to PISA 2015, the average of all countries in the field of reading skills is 460, and 465 in the field of science literacy. Turkey's average in the field of reading skills is 428 , and 425 in the field of science literacy. These results show the proximity of scores 
between reading skills and science literacy in PISA. These data are the indicator that the young in our country has almost the same level of reading skills and science literacy and that they are quite below the average of all countries.

PISA 2015 has defined seven levels of competence in its field. While the ration of students at the first level and below in terms of science literacy in Turkey (lower level of competence) is $44.4 \%$, the ration of students at the fifth level and above (top level of competence) is $0.3 \%$. While the ration of students at the first level and below in terms of reading skills (lower level of competence) is $30 \%$, the ration of students at the fifth level and above (tope level of competence) is $0.06 \%$. These data indicate that almost half the students in our country aren't science literate, approximately one-third of them do not have reading skills; we have almost no students at the top level in both science literacy and reading skills (MEB, 2015).

The report of reading habits, reading skills and science literacy of Turkey is as above. Similarly, Turkey is sadly also quite unsuccessful in the field of biology. For example, while the average number of correct answers in biology questions of the university exam Field Proficiency Test (AYT) was 1.669 in 13 questions in 2018; it was 1.298 in the year of 2019. These two results show not only the lowness of the average of correct answers in biology questions in the university exam but also although it should improve it shows an extra decrease compared to the previous year.

No academic research has been encountered examining the relationship between book reading habit and course success. For this reason, this study has a unique value in its field. This research is based on the problem of whether reading habits have any effects on the academic achievement of the biology course of high school students and reaching the answer to this question has been aimed. It is hoped that the research will help to remedy this deficiency and make a significant contribution to the literature with the results.

\section{Method}

\subsection{Model of Research}

Qualitative and quantitative research approaches were used together in the research. The screening model from the quantitative research models was used in order to determine the book reading habits of the participants. The relational screening model was preferred among the screening models. This model is the research approach that aims to determine the existence and/or degree of co-change between two or more variables (Karasar, 2009). In order to determine the perception of the participants' book reading through metaphor, the phenomenological approach was used. In the phenomenological approach, the researcher mainly deals with personal experiences of the participants, examines the individuals' perceptions and the meaning they attach to events (Baş and Akturan, 2013). 


\subsection{Study Group of the Research}

The study group of this research consists of $282(n=282)$ students who study in the final years of various high schools in the province of Kars and took biology courses before. The data collection tool of the research was filled by 282 students, however, 16 data were excluded from the research since they weren't filled properly, the data obtained from 266 students in total were included in the analysis process of the research. Easily accessible status sampling technique was used to determine the study group with the aim of giving the research speed and practicality. The demographic information of the study group is presented in Table 1.

Table 1: Demographic information of the study group

\begin{tabular}{llr}
\hline Variables & & $\mathbf{N}$ \\
\hline \multirow{2}{*}{$\begin{array}{l}\text { Type of } \\
\text { high school }\end{array}$} & Science High School & 78 \\
\cline { 2 - 3 } & Anatolian High School & 112 \\
\cline { 2 - 3 } Gender & Vocational and Technical High School & 76 \\
\hline \multirow{4}{*}{$\begin{array}{ll}\text { Academic achievements } \\
\text { in the biology course }\end{array}$} & Female & 204 \\
\cline { 2 - 3 } & Male & 62 \\
\cline { 2 - 3 } & 4-44 (unsuccessful) & 4 \\
\cline { 2 - 3 } & 55-54 (passing) & 49 \\
\cline { 2 - 3 } & $70-84$ (middle) & 77 \\
\hline
\end{tabular}

\subsection{Data Collecting Tools of the Research}

Data of the research was collected by a questionnaire prepared by the researchers. The literature review was conducted and similar researches were examined in the preparation process of the questionnaire. Then, 11 questions were prepared 4 of which would help determine the variables of their current school type, education fields (numerical, verbal, equal weight), their gender, school report grades of biology course, 5 of which were thought to be able to determine their reading habits being 5 closed-ended and 2 openended. In order to determine the students' perception of book reading through metaphor, a questionnaire of 12 questions was also prepared by adding questions such as "Book reading is like............. to me. Because...........". The questionnaire was examined by experts in educational sciences in order to determine the validity of appearance and necessary corrections were made in line with the recommendations of experts.

\subsection{Analysis of Research Data}

In the research, frequency and percentage values were calculated for the descriptive analysis of the answers students gave to the questionnaire items. Chi-square analysis was used when examining the relationship between the students' demographic characteristics and book-reading habits. When the degree of freedom is greater than 1 and the number of cells with the expected value which is less than five exceeds $20 \%$ of the total number of cells, then the comments were made using only frequency and percentages on the crosstab (Büyüköztürk, 2007). The content analysis technique was used in the analysis of 
metaphors. In this process a list of the metaphors produced by the students was made primarily, expressions not having metaphor characteristics or whose reasons for metaphor did not conform to the logical grounds were eliminated. The coded metaphors were gathered under one single category considering their common characteristics. Whether the metaphors produced by the students represent the conceptual categories in which they are placed is presented to the view of experts in educational sciences. The reliability of the research was calculated using the formula (Reliability = consensus/consensus + disagreement) developed by Miles and Huberman (1994) and the reliability level was found $90 \%$.

\section{Findings}

Frequency and percentage values of the responses of the participant students to the questionnaire items prepared to determine the book reading habits are given in Table 2 below.

Table 2: Descriptive analysis of the students' responses to the questionnaire items

\begin{tabular}{|c|c|c|c|}
\hline Variables & & $\mathrm{f}$ & $\%$ \\
\hline \multirow{2}{*}{$\begin{array}{l}\text { Avariables } \\
\text { Availability of library } \\
\text { at home }\end{array}$} & Available & 210 & 78.9 \\
\hline & Absent & 56 & 21.1 \\
\hline \multirow{5}{*}{$\begin{array}{l}\text { The average number } \\
\text { of books per month }\end{array}$} & I never read & 53 & 19.9 \\
\hline & 1 & 73 & 27.4 \\
\hline & 2 & 73 & 27.4 \\
\hline & 3 & 45 & 16.9 \\
\hline & 4 and more & 22 & 8.3 \\
\hline \multirow{4}{*}{$\begin{array}{l}\text { Time spared for reading } \\
\text { per day }\end{array}$} & I don't spare time & 59 & 22.2 \\
\hline & Less than 1 hour & 100 & 37.6 \\
\hline & 1-2 hours & 92 & 34.6 \\
\hline & 3-4 hours & 15 & 5.6 \\
\hline \multirow{5}{*}{$\begin{array}{l}\text { Nonstop reading } \\
\text { time at a time }\end{array}$} & Maximum half an hour & 47 & 17.7 \\
\hline & Maximum 1 hour & 85 & 32 \\
\hline & 2 hours & 74 & 27.8 \\
\hline & 3 hours & 21 & 7.9 \\
\hline & 4 hours and more & 39 & 14.7 \\
\hline \multirow{3}{*}{$\begin{array}{l}\text { Type of book } \\
\text { to read }\end{array}$} & Novel/story & 227 & 85.3 \\
\hline & Science & 18 & 6.8 \\
\hline & Other (fairy tale, poetry, picture book, etc.) & 21 & 7.9 \\
\hline
\end{tabular}

When Table 2 is examined, approximately $79 \%(n=210)$ of the students participating in the research stated that they have a library in their homes. $27.4 \%(n=73)$ of the students stated that they read one book on average monthly, $27.4 \%(n=73)$ of the students stated that they read two books on average monthly. 37.6\% $(n=100)$ of the participants stated that they spare less than an hour in average for reading daily, 32\% $(n=85)$ of them stated that they can read nonstop for maximum 1 hour at a time and $85 \%(n=227)$ of them stated that they read novel/story types of books. 
In Table 3 below, the results of chi-square analysis is presented showing the relationship between availability of library in their homes, average number of books they read monthly, time they spare for reading daily, nonstop reading time at a time and type of books they read according to the variable of participant students' school types.

Table 3: Results of chi-square analysis of responses to the questionnaire items according to school type variable

\begin{tabular}{|c|c|c|c|c|c|c|c|c|}
\hline \multirow{2}{*}{\multicolumn{2}{|c|}{ School Type }} & \multicolumn{7}{|c|}{ Availability of Library } \\
\hline & & \multicolumn{2}{|c|}{ Available } & \multicolumn{3}{|c|}{ Absent } & \multicolumn{2}{|c|}{ Total } \\
\hline \multirow{2}{*}{$\begin{array}{l}\text { Vocational and Technical } \\
\text { High School }\end{array}$} & $\mathrm{f}$ & \multicolumn{2}{|l|}{45} & \multicolumn{3}{|c|}{31} & \multicolumn{2}{|l|}{76} \\
\hline & $\%$ & \multicolumn{2}{|c|}{59.2} & \multicolumn{3}{|c|}{40.8} & \multicolumn{2}{|c|}{100} \\
\hline \multirow{2}{*}{ Anatolian High School } & $\mathrm{f}$ & \multicolumn{2}{|c|}{102} & \multicolumn{3}{|c|}{10} & \multicolumn{2}{|c|}{112} \\
\hline & $\%$ & \multicolumn{2}{|c|}{91.1} & \multicolumn{3}{|c|}{8.9} & \multicolumn{2}{|c|}{100} \\
\hline \multirow{2}{*}{ Science High School } & $\mathrm{f}$ & \multicolumn{2}{|l|}{63} & \multicolumn{3}{|c|}{15} & \multicolumn{2}{|l|}{78} \\
\hline & $\%$ & \multicolumn{2}{|c|}{80.8} & \multicolumn{3}{|c|}{19.2} & \multicolumn{2}{|c|}{100} \\
\hline \multicolumn{9}{|l|}{$\left(\chi^{2}=27.87, \mathrm{sd}=2, \mathrm{p}=.00\right)$} \\
\hline & & & erage $\mathrm{N}$ & nber & of $B$ & oks $\operatorname{Re}$ & Monthly & \\
\hline School Type & & $\begin{array}{c}\text { I never } \\
\text { read }\end{array}$ & $\begin{array}{c}\text { I read } \\
1 \\
\end{array}$ & $\begin{array}{r}\text { I re } \\
2 \\
\end{array}$ & & $\begin{array}{c}\text { I read } \\
3 \\
\end{array}$ & $\begin{array}{c}\text { I read } 4 \text { and } \\
\text { more }\end{array}$ & Total \\
\hline Vocational and Technical & $\mathrm{f}$ & 10 & 20 & 22 & & 18 & 6 & 76 \\
\hline High School & $\%$ & 13.2 & 26.3 & 28. & & 23.7 & 7.9 & 100.0 \\
\hline Anatolian High Sohol & $\mathrm{f}$ & 19 & 33 & 30 & & 19 & 11 & 112 \\
\hline Anatoman rign scnoor & $\%$ & 17.0 & 29.5 & 26. & & 17.0 & 9.8 & 100.0 \\
\hline & $\mathrm{f}$ & 24 & 20 & 21 & & 8 & 5 & 78 \\
\hline Science High School & $\%$ & 30.8 & 25.6 & 26. & & 10.3 & 6.4 & 100.0 \\
\hline$\left(\chi^{2}=11.99, \mathrm{sd}=8, \mathrm{p}=.15\right)$ & & & & & & & & \\
\hline & & & Time & pared & $10 \mathrm{r}$ & Readin & aily & \\
\hline School Type & & $\begin{array}{c}\text { I don't } \\
\text { spare time }\end{array}$ & $\begin{array}{r}\text { Less } \\
\mathrm{h} \\
\end{array}$ & an 1 & & & & \\
\hline Vocational and Technical & $\mathrm{f}$ & 11 & & & & & 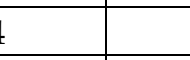 & \\
\hline High School & $\%$ & 14.5 & & & & & 3 & \\
\hline Anotolian High School & $\mathrm{f}$ & 23 & & & & & 5 & \\
\hline Anatolian High School & $\%$ & 20.5 & & & & & 5 & \\
\hline Scionse Hiorh Sohool & $\mathrm{f}$ & 25 & & & & & 5 & \\
\hline Science High School & $\%$ & 32.1 & & & & & 7 & \\
\hline$\left(\chi^{2}=9.65, \mathrm{sd}=6, \mathrm{p}=.14\right)$ & & & & & & & & \\
\hline & & & Nonst & Rea & (n) & Time at & ime & \\
\hline School Type & & $\begin{array}{l}\text { Max half } \\
\text { an hour }\end{array}$ & $\begin{array}{c}\text { Max } 1 \\
\text { hour }\end{array}$ & $\begin{array}{r}2 \\
\text { hou }\end{array}$ & & $\begin{array}{c}3 \\
\text { hours }\end{array}$ & $\begin{array}{l}4 \text { hours } \\
\text { and more }\end{array}$ & Total \\
\hline Vocational and Technical & $\mathrm{f}$ & 17 & 32 & 18 & & 7 & 2 & 76 \\
\hline High School & $\%$ & 22.4 & 42.1 & 23. & & 9.2 & 2.6 & 100.0 \\
\hline Anatolian High School & $\mathrm{f}$ & 15 & 32 & 34 & & 7 & 24 & 112 \\
\hline Anatolian High School & $\%$ & 13.4 & 28.6 & 30. & & 6.3 & 21.4 & 100.0 \\
\hline & $\mathrm{f}$ & 15 & 21 & 22 & & 7 & 13 & 78 \\
\hline science High school & \begin{tabular}{|l|}
$\%$ \\
\end{tabular} & 19.2 & 26.9 & 28. & & 9 & 16.7 & 100.0 \\
\hline
\end{tabular}

$\left(\chi^{2}=18.29, \mathrm{sd}=8, \mathrm{p}=.01\right)$ 


\begin{tabular}{|l|c|c|c|c|c|}
\hline \hline \multirow{2}{*}{ Type of School } & \multicolumn{4}{|c|}{ Type of Book } \\
\cline { 2 - 6 } \multicolumn{2}{l|}{} & \multirow{2}{*}{ Novel/story } & $\begin{array}{c}\text { Science } \\
\text { books }\end{array}$ & \multirow{2}{*}{ Other } & \multirow{2}{*}{ Total } \\
\hline $\begin{array}{l}\text { Vocational and Technical } \\
\text { High School }\end{array}$ & $\mathrm{f}$ & 69 & 3 & 4 & 76 \\
\cline { 2 - 6 } & $\%$ & 90.8 & 3.9 & 5.3 & 100.0 \\
\hline \multirow{2}{*}{ Anatolian High School } & $\mathrm{f}$ & 93 & 11 & 8 & 112 \\
\cline { 2 - 6 } & $\%$ & 83.0 & 9.8 & 7.1 & 100.0 \\
\hline \multirow{2}{*}{ Science High School } & $\mathrm{f}$ & 65 & 4 & 9 & 100.0 \\
\cline { 2 - 6 } & $\%$ & 83.3 & 5.1 & 11.5 & \\
\hline$\left(\chi^{2}=5.17, \mathrm{sd}=4, \mathrm{p}=.27\right)$ & \multicolumn{5}{|l}{} \\
\hline
\end{tabular}

According to Table 3, it was found that the participating students' availability of library changes according to school type $\left(\chi^{2}=27.87, \mathrm{p}=.00<.05\right)$, approximately $91 \%(\mathrm{n}=102)$ of the Anatolian High School students, approximately $81 \%(n=63)$ of the Science High School students and approximately $59 \%(n=45)$ of the Vocational and Technical High School students have libraries in their homes. In addition, majority of the Vocational and Technical High School students $(\mathrm{n}=22,28.9 \%)$ stated that they read 2 books in average monthly, majority of the Anatolian High School students ( $\mathrm{n}=33,29.5 \%)$ stated that they read 1 book in average monthly and majority of the Science High School students ( $\mathrm{n}=24$, $30.8 \%$ ) stated that they don't read any books in average monthly. However, no meaningful relationship was found between the number of books they read monthly according to school type variable $\left(\chi^{2}=11.99, \mathrm{p}=.15>.05\right)$. When Table 3 is examined, it is seen that $42 \%$ of the Vocational and Technical High School students $(n=32)$ spare 1-2 hours in average for reading daily, $41 \%$ of the Anatolian High School students $(n=46)$ spare less than 1 hour and $32 \%$ of the Science High School students $(n=25)$ spare less than 1 hour, $32 \%$ of them $(n=25)$ spare no time at all. However, as a result of the analysis conducted no meaningful relationship was found between the time the students spare for reading daily according to the school type they study $\left(\chi^{2}=9.65, \mathrm{p}=.14>.05\right)$. According to Table 3, a meaningful relationship was found between the participating high school students' nonstop reading time at a time according to the school type $\left(\chi^{2}=18.29\right.$, $\mathrm{p}=.01<.05)$. According to this, it was found that Vocational and Technical High School students can read nonstop for a maximum of 1 hour at a time, the majority of Anatolian and Science High School students can read nonstop for 2 hours at a time. As a result of the analyses conducted, it was found that there is no relationship between the book type according to school type $\left(\chi^{2}=5.17, \mathrm{p}=.27>.05\right)$, the majority of the students studying at all three types of schools stated that they read mostly novels/stories.

In Table 4 presented below, chi-square and descriptive analysis results are presented showing the relationship between the availability of library, the number of books they read monthly, time they spare for reading daily, nonstop reading time at a time and book type they read according to the gender variable of the participating students' gender variable. 
Table 4: Chi-square and descriptive analysis results of the responses to the questionnaire items according to gender variable

\begin{tabular}{|c|c|c|c|c|c|c|c|c|}
\hline \multirow{2}{*}{\multicolumn{2}{|c|}{ Gender }} & \multicolumn{7}{|c|}{ Availability of Library } \\
\hline & & \multirow{2}{*}{\multicolumn{2}{|c|}{$\begin{array}{c}\text { Available } \\
52\end{array}$}} & \multicolumn{3}{|c|}{ Absent } & \multicolumn{2}{|c|}{ Total } \\
\hline \multirow[t]{2}{*}{ Female } & $\mathrm{f}$ & & & \multicolumn{3}{|c|}{10} & \multicolumn{2}{|c|}{62} \\
\hline & $\%$ & \multicolumn{2}{|c|}{83.9} & \multicolumn{3}{|c|}{16.1} & \multicolumn{2}{|c|}{100.0} \\
\hline \multirow[t]{2}{*}{ Male } & $\mathrm{f}$ & \multicolumn{2}{|c|}{158} & \multicolumn{3}{|c|}{46} & \multicolumn{2}{|c|}{204} \\
\hline & $\%$ & \multicolumn{2}{|c|}{77.5} & & \\
\hline \multirow{2}{*}{\multicolumn{9}{|c|}{$\left(\chi^{2}=1.17, \mathrm{sd}=1, \mathrm{p}=.27\right)$}} \\
\hline & & & & & & & & \\
\hline \multicolumn{2}{|l|}{ Gender } & $\begin{array}{c}\text { I never } \\
\text { read }\end{array}$ & $\begin{array}{c}\text { I read } \\
1\end{array}$ & \multicolumn{2}{|l|}{$\begin{array}{c}\text { I read } \\
2\end{array}$} & $\begin{array}{c}\text { I read } \\
3\end{array}$ & $\begin{array}{c}\text { I read } 4 \\
\text { and more }\end{array}$ & Total \\
\hline \multirow[t]{2}{*}{ Female } & $\mathrm{f}$ & 27 & 17 & \multicolumn{2}{|l|}{12} & 5 & 1 & 62 \\
\hline & $\%$ & 43.5 & 27.4 & 19.4 & & 8.1 & 1.6 & 100.0 \\
\hline Male & $\mathrm{f}$ & 26 & 56 & 61 & & 40 & 21 & 204 \\
\hline & $\%$ & 12.7 & 27.5 & 2.9 & & 19.6 & 10.3 & 100.0 \\
\hline$\left(\chi^{2}=32.6\right.$ & $\mathrm{sd}=$ & $p=.00)$ & & & & & & \\
\hline Condon & & & & Time Spared f & or Readi & ig Daily & & \\
\hline Gender & & I do not s] & time & Less than 1 hour & $1-2 \mathrm{ho}$ & & 4 hours & Total \\
\hline Female & $\mathrm{f}$ & 2 & & 22 & 13 & & 0 & 62 \\
\hline & $\%$ & 43 & & 35.5 & 21. & & 0 & 100.0 \\
\hline Male & $\mathrm{f}$ & 3 & & 78 & 79 & & 15 & 204 \\
\hline & \% & 15 & & 38.2 & 38.7 & & 7.4 & 100.0 \\
\hline$\left(\chi^{2}=25.6\right.$ & $\mathrm{sd}=$ & $p=.00)$ & & & & & & \\
\hline & & & & Nonstop Readi & ig Time & at a Time & & \\
\hline Gender & & $\begin{array}{r}\text { Hal } \\
\text { hour ma }\end{array}$ & & $\begin{array}{c}\text { 1-hour } \\
\text { maximum }\end{array}$ & $\begin{array}{c}2 \\
\text { hours }\end{array}$ & $\begin{array}{c}3 \\
\text { hours }\end{array}$ & $\begin{array}{l}4 \text { hours } \\
\text { and more }\end{array}$ & Total \\
\hline Female & $\mathrm{f}$ & 1 & & 32 & 18 & 7 & 2 & 76 \\
\hline & \begin{tabular}{|l|}
$\%$ \\
\end{tabular} & 22 & & 42.1 & 23.7 & 9.2 & 2.6 & 100.0 \\
\hline Male & $\mathrm{f}$ & 1 & & 32 & 34 & 7 & 24 & 112 \\
\hline & $\%$ & 13 & & 28.6 & 30.4 & 6.3 & 21.4 & 100.0 \\
\hline$\left(\chi^{2}=3.33\right.$, & $s d=4$ & $=.50)$ & & & & & & \\
\hline Candor & & & & Boo & К Type & & & \\
\hline Gender & & Novel & & Science book & & Other & & tal \\
\hline Female & $\mathrm{f}$ & 6 & & 3 & & 4 & & 6 \\
\hline & $\%$ & 90 & & 3.9 & & 5.3 & & 0.0 \\
\hline Male & $\mathrm{f}$ & 9 & & 11 & & 8 & & 12 \\
\hline & \begin{tabular}{|l|}
$\%$ \\
\end{tabular} & 83 & & 9.8 & & 7.1 & & 0.0 \\
\hline
\end{tabular}

Table 4 shows that there is no meaningful relationship between the availability of the library according to the gender of participating students $\left(\chi^{2}=1.17, \mathrm{p}=.27>.05\right)$. This result can be interpreted as female and male students are similar in the availability of the library in their homes. It was found that there is a meaningful relationship between the number of books the participating students read according to gender $\left(\chi^{2}=32.64, p=.00<.05\right)$, majority of the female students $(n=61)$ read 2 books in average monthly, majority of the male students $(n=27)$ don't read any books at all. When Table 4 is examined, it is seen that there is a meaningful relationship between the time the high school students spare for 
reading daily according to gender variable $\left(\chi^{2}=25.63, p=.00<.05\right)$, majority of the male students $(n=27)$ don't spare any time at all for reading but majority of the female students $(n=79)$ spare 1-2 hours in average daily for reading. However, it is among the finding of the study that there is no meaningful relationship between the students' nonstop reading time at a time according to the gender variable $\left(\chi^{2}=3.33, p=.50<.05\right)$. According to the descriptive analysis results conducted on the relationship between book types according to the gender variable, approximately $65 \%$ of the participating male students and approximately $92 \%$ of the female students prefer novels/stories. While $15 \%$ of the male students stated that they read science books, this rate is $4 \%$ for females. The rate of books in the content of other categories (poetry, picture book, encyclopedia, fairy tale) $21 \%$ for male students, $4 \%$ for female students.

In Table 5, descriptive analysis results showing the relationship between the questionnaire items according to the participating students' academic achievement level variable of the biology course.

Table 5: Descriptive analysis results of the responses to the questionnaire items according to the academic achievement level variable of biology course

\begin{tabular}{|c|c|c|c|c|c|c|c|}
\hline \multirow{2}{*}{\multicolumn{2}{|c|}{$\begin{array}{l}\text { The academic } \\
\text { achievement level } \\
\text { of biology course } \\
\text { (score) }\end{array}$}} & \multicolumn{6}{|c|}{ Availability of library } \\
\hline & & \multicolumn{2}{|c|}{ Available } & \multicolumn{2}{|c|}{ Absent } & \multicolumn{2}{|c|}{ Total } \\
\hline \multirow[t]{2}{*}{$0-44$} & $\mathrm{f}$ & \multicolumn{2}{|c|}{4} & \multicolumn{2}{|c|}{0} & \multicolumn{2}{|c|}{4} \\
\hline & $\%$ & \multicolumn{2}{|c|}{100.0} & \multicolumn{2}{|c|}{.0} & \multicolumn{2}{|c|}{100.0} \\
\hline \multirow[t]{2}{*}{$45-54$} & $\mathrm{f}$ & \multicolumn{2}{|c|}{12} & \multicolumn{2}{|c|}{3} & \multicolumn{2}{|c|}{15} \\
\hline & $\%$ & \multicolumn{2}{|c|}{80.0} & \multicolumn{2}{|c|}{20.0} & \multicolumn{2}{|c|}{100.0} \\
\hline \multirow[t]{2}{*}{$55-69$} & $\mathrm{f}$ & \multicolumn{2}{|c|}{35} & \multicolumn{2}{|c|}{14} & \multicolumn{2}{|c|}{49} \\
\hline & $\%$ & \multicolumn{2}{|c|}{71.4} & \multicolumn{2}{|c|}{28.6} & \multicolumn{2}{|c|}{100.0} \\
\hline \multirow[t]{2}{*}{$70-84$} & $\mathrm{f}$ & \multicolumn{2}{|c|}{100} & \multicolumn{2}{|c|}{21} & \multicolumn{2}{|c|}{121} \\
\hline & $\%$ & \multicolumn{2}{|c|}{82.6} & \multicolumn{2}{|c|}{17.4} & \multicolumn{2}{|c|}{100.0} \\
\hline $85-100$ & $\mathrm{f}$ & & & 18 & & & \\
\hline & $\%$ & & & 23. & & & \\
\hline The ace & & & umber & nthly R & ad Boo & in Average & \\
\hline $\begin{array}{l}\text { achieve } \\
\text { of biol } \\
\text { (score) }\end{array}$ & $\begin{array}{l}\text { evel } \\
\text { urse }\end{array}$ & $\begin{array}{l}\text { I never } \\
\text { read }\end{array}$ & $\begin{array}{c}\text { I read } \\
1\end{array}$ & $\begin{array}{c}\text { I read } \\
2\end{array}$ & $\begin{array}{c}\text { I read } \\
3\end{array}$ & $\begin{array}{l}\text { I read } 4 \text { and } \\
\text { more }\end{array}$ & Total \\
\hline $0-44$ & $\mathrm{f}$ & 1 & 1 & 0 & 1 & 1 & 4 \\
\hline & $\%$ & 25.0 & 25.0 & .0 & 25.0 & 25.0 & 100.0 \\
\hline $45-54$ & $\mathrm{f}$ & 1 & 8 & 3 & 2 & 1 & 15 \\
\hline & $\%$ & 6.7 & 53.3 & 20.0 & 13.3 & 6.7 & 100.0 \\
\hline $55-69$ & $\mathrm{f}$ & 11 & 11 & 12 & 10 & 5 & 49 \\
\hline & $\%$ & 22.4 & 22.4 & 24.5 & 20.4 & 10.2 & 100.0 \\
\hline $70-84$ & $\mathrm{f}$ & 23 & 30 & 34 & 24 & 10 & 121 \\
\hline & $\%$ & 19.0 & 24.8 & 28.1 & 19.8 & 8.3 & 100.0 \\
\hline $85-100$ & $\mathrm{f}$ & 17 & 23 & 24 & 8 & 5 & 77 \\
\hline & $\%$ & 22.1 & 29.9 & 31.2 & 10.4 & 6.5 & 100.0 \\
\hline
\end{tabular}




\begin{tabular}{|c|c|c|c|c|c|c|c|}
\hline \multirow{2}{*}{\multicolumn{2}{|c|}{$\begin{array}{l}\text { The academic } \\
\text { achievement level of } \\
\text { biology course (score) }\end{array}$}} & \multicolumn{6}{|c|}{ Time Spared for Reading Daily } \\
\hline & & \multirow{2}{*}{$\begin{array}{c}\text { I do not spare } \\
\text { any time } \\
0\end{array}$} & \multirow{2}{*}{$\begin{array}{c}\text { Less than } \\
1 \text { hour } \\
2\end{array}$} & \multirow{2}{*}{$\begin{array}{c}\begin{array}{c}1-2 \\
\text { hours }\end{array} \\
2\end{array}$} & \multirow{2}{*}{\multicolumn{2}{|c|}{\begin{tabular}{c|c}
$\begin{array}{c}3-4 \\
\text { hours }\end{array}$ \\
\end{tabular}}} & \multirow{2}{*}{$\begin{array}{c}\text { Total } \\
4 \\
\end{array}$} \\
\hline \multirow[t]{2}{*}{$0-44$} & $\mathrm{f}$ & & & & & & \\
\hline & $\%$ & .0 & 50.0 & 50. & & .0 & 100.0 \\
\hline \multirow[t]{2}{*}{$45-54$} & $\mathrm{f}$ & 2 & 9 & 4 & & 0 & 15 \\
\hline & $\%$ & 13.3 & 60.0 & 26.7 & & .0 & 100.0 \\
\hline \multirow[t]{2}{*}{$55-69$} & $\mathrm{f}$ & 13 & 16 & 19 & & 1 & 49 \\
\hline & $\%$ & 26.5 & 32.7 & 38.8 & & 2.0 & 100.0 \\
\hline \multirow[t]{2}{*}{$70-84$} & $\mathrm{f}$ & 27 & 43 & 40 & & 11 & 121 \\
\hline & $\%$ & 22.3 & 35.5 & 33. & & 9.1 & 100.0 \\
\hline \multirow[t]{2}{*}{$85-100$} & $\mathrm{f}$ & 17 & 30 & 27 & & 3 & 77 \\
\hline & $\%$ & 22.1 & 39.0 & 35. & & 3.9 & 100.0 \\
\hline \multirow{2}{*}{\multicolumn{2}{|c|}{$\begin{array}{l}\text { The academic } \\
\text { achievement level of } \\
\text { biology course (score) }\end{array}$}} & \multicolumn{6}{|c|}{ Nonstop Reading Time at a Time } \\
\hline & & $\begin{array}{l}\text { Half an hour } \\
\text { maximum }\end{array}$ & $\begin{array}{c}\text { 1-hour } \\
\text { maximum }\end{array}$ & $\begin{array}{c}2 \\
\text { hours }\end{array}$ & $\begin{array}{c}3 \\
\text { hours }\end{array}$ & \begin{tabular}{|c|}
4 hours \\
and more
\end{tabular} & Total \\
\hline \multirow[t]{2}{*}{$0-44$} & $\mathrm{f}$ & 0 & 1 & 2 & 0 & 1 & 4 \\
\hline & $\%$ & .0 & 25.0 & 50.0 & .0 & 25.0 & 100.0 \\
\hline \multirow[t]{2}{*}{$45-54$} & $\mathrm{f}$ & 4 & 2 & 8 & 1 & 0 & 15 \\
\hline & $\%$ & 26.7 & 13.3 & 53.3 & 6.7 & .0 & 100.0 \\
\hline \multirow[t]{2}{*}{$55-69$} & $\mathrm{f}$ & 12 & 19 & 9 & 4 & 5 & 49 \\
\hline & $\%$ & 24.5 & 38.8 & 18.4 & 8.2 & 10.2 & 100.0 \\
\hline \multirow[t]{2}{*}{$70-84$} & $\mathrm{f}$ & 20 & 43 & 33 & 9 & 16 & 121 \\
\hline & $\%$ & 16.5 & 35.5 & 27.3 & 7.4 & 13.2 & 100.0 \\
\hline \multirow[t]{2}{*}{$85-100$} & $\mathrm{f}$ & 11 & 20 & 22 & 7 & 17 & 77 \\
\hline & $\%$ & 14.3 & 26.0 & 28.6 & 9.1 & 22.1 & 100.0 \\
\hline \multirow{2}{*}{\multicolumn{2}{|c|}{$\begin{array}{l}\text { The academic } \\
\text { achievement level of } \\
\text { biology course (score) }\end{array}$}} & \multicolumn{6}{|c|}{ Book Type } \\
\hline & & Novel/story & Science books & & Other & & Total \\
\hline \multirow[t]{2}{*}{$0-44$} & $\mathrm{f}$ & 4 & 0 & & 0 & & 4 \\
\hline & $\%$ & 100.0 & .0 & & .0 & & 100.0 \\
\hline \multirow[t]{2}{*}{$45-54$} & $\mathrm{f}$ & 13 & 0 & & 2 & & 15 \\
\hline & $\%$ & 86.7 & .0 & & 13.3 & & 100.0 \\
\hline \multirow[t]{2}{*}{$55-69$} & $\mathrm{f}$ & 39 & 4 & & 6 & & 49 \\
\hline & $\%$ & 79.6 & 8.2 & & 12.2 & & 100.0 \\
\hline \multirow[t]{2}{*}{$70-84$} & $\mathrm{f}$ & 104 & 10 & & 7 & & 121 \\
\hline & $\%$ & 86.0 & 8.3 & & 5.8 & & 100.0 \\
\hline \multirow[t]{2}{*}{$85-100$} & $f$ & 67 & 4 & & 6 & & 77 \\
\hline & $\%$ & 87.0 & 5.2 & & 7.8 & & 100.0 \\
\hline
\end{tabular}

According to Table 5, all of the participating students having academic achievement levels of biology course scores between $0-44(100 \%), 80 \%$ of the students having academic achievement scores between $45-54$ of $(n=12)$ have libraries in their homes. The majority of the students having academic achievement scores 55 and below stated that they have libraries in their homes. In addition, when Table 5 is examined it is seen that the number of books the students having academic achievement scores between 0-44 read monthly is distributed to the choices equally. $25 \%$ of the students $(n=1)$ having achievement scores between 0-44 stated that they almost never read; $25 \%(n=1)$ stated that they read 1 book 
monthly, $25 \%$ of the students $(n=1)$ stated that they read 3 books monthly, the rest $25 \%$ of the students $(n=1)$ stated that they read 4 or more books in average monthly. It was found that majority of the students $(53 \%, n=8)$ having academic achievement of biology course scores between 45-54 read 1 book in average monthly; majority of the students having scores between 55-69 $(24.5 \%, n=12)$ read 2 books in average monthly; $28 \%(n=34)$ having scores between $70-84$ read 2 books in average monthly; $31 \%$ of the students $(n=24)$ having scores between 85-100 read 2 books in average monthly. It is observed that $50 \%$ of the students having academic achievement scores of biology course between 0-44 (n=2) spare less than 1 hour for reading daily, the rest 50\% (n=2) spare about 1-2 hours for reading daily. It was found that majority of the students $(60 \%, n=9)$ having achievement scores between 45-54 spare less than 1 hour for reading daily, 39\% of them $(n=19)$ between 5569 spare 1-2 hours, majority of the students $(35.5 \%, n=43)$ between the scores $70-84$ spare less than 1 hour, 39\% of the students $(n=30)$ between $85-100$ spare less than 1 hour in average for reading daily. When Table 5 is examined, it is seen that $50 \%$ of the students having academic achievement scores of biology course between 0-44 read nonstop for 2 hours at a time, $53 \%$ of them $(n=8)$ having scores between $45-54$ read nonstop for 2 hours at a time, 39\% (n=19) of them having scores between 55-69 read nonstop for a maximum of 1 hour at a time, $35.5 \%$ of them $(n=43)$ having scores between $70-84$ read nonstop for a maximum of 1 hour at a time and $29 \%$ of the students $(n=22)$ having scores between 85 100 read nonstop for 2 hours at a time. When the relationship between the participating high school students' academic achievement levels of biology course and book types was examined, it was found that the students in all achievement groups mostly prefer novels/stories.

In Table 6 the list of the books the participating students read in summer and their frequency levels are presented.

Table 6: The books the participants read in summer and their frequency values

\begin{tabular}{|c|c|c|c|c|c|}
\hline Name of the Book & $\mathbf{f}$ & Name of the Book & $\mathrm{f}$ & Name of the Book & $\mathbf{f}$ \\
\hline Eylül & 14 & En Son Yürekler Ölür & 4 & Abim Deniz & 2 \\
\hline Sherlock Holmes-1 & 13 & Taaşşuk-1 Talat ve Fitnat & 4 & Aklından Bir Sayı Tut & 2 \\
\hline Suç ve Ceza & 12 & Çalıkuşu & 4 & Albert Camus & 2 \\
\hline Dokuzuncu Hariciye Koğuşu & 11 & $\begin{array}{l}\text { Beyoğlu'nun En Güzel } \\
\text { Abisi }\end{array}$ & 4 & Amok Koşucusu & 2 \\
\hline Araba Sevdası & 10 & Homo Sapiens & 4 & $\begin{array}{l}\text { Bir İdam Mahkumunun Son } \\
\text { Günü }\end{array}$ & 2 \\
\hline Gün Olur Asra Bedel & 10 & Ölü Canlar & 4 & Bir Kedi, Bir Adam, Bir Ölüm & 2 \\
\hline Kürk Mantolu Madonna & 10 & Toprak Ana & 4 & Bilinmeyen Bir Kadının Mektubu & 2 \\
\hline Serenad & 9 & Kuyucaklı Yusuf & 4 & Cehennem & 2 \\
\hline Sergüzeşt & 9 & Piraye & 4 & Cemile & 2 \\
\hline Huzursuzluk & 8 & Aşk ve Gurur & 3 & Cengiz Han & 2 \\
\hline Sefiller & 8 & Savaş ve Barış & 3 & Cosmos & 2 \\
\hline Psikopat & 8 & Senden Önce Ben & 3 & Çikolata Hırsızı & 2 \\
\hline Çalıkuşu & 7 & Vazgeçtim & 3 & Dede Korkut Hikayeleri & 2 \\
\hline Sherlock Holmes-2 & 7 & Bab-1 Esrar & 3 & $\mathrm{Fi}$ & 2 \\
\hline Sherlock Holmes-3 & 7 & Çı̆̆lık & 3 & Vampirin Günlüğü & 2 \\
\hline İntibah & 7 & Dönüşüum & 3 & Vatan Yahut Silistre & 2 \\
\hline Kötü Çocuk-1 & 7 & Homo Deus & 3 & Yüreğim Seni Çok Sevdi & 2 \\
\hline
\end{tabular}



ACHIEVEMENT OF HIGH SCHOOL STUDENTS IN BIOLOGY COURSE

\begin{tabular}{llllll}
\hline \hline Uçurtma Avcısı & 7 & Fatih Harbiye & 3 & Zamanın Kısa Bir Tarihi & 2 \\
\hline Sol Ayağım & 6 & Satranç & 3 & Şu Çılgın Türkler & 2 \\
\hline Bin Muhteşem Güneş Suns & 6 & Sen On Yedi Yaşımsın & 3 & Şeker Portakalı & 2 \\
\hline Kardesimin Hikayesi & 6 & Kırmızı Saçlı Kadın & 3 & Nutuk & 2 \\
\hline Olasılıksız & 6 & Küçük Ağa & 3 & Od & 2 \\
\hline Beyaz Diş & 5 & Şah ve Sultan & 3 & Ölüme Fısıldayan Adam & 2 \\
\hline 4n1k-1 & 5 & Agapi & 2 & Sabah Uykum & 2 \\
\hline Aşk-1 Memnu & 5 & Köle & 2 & Havva'nın Üç Kızı & 2 \\
\hline Ateşten Gömlek & 5 & Tanrıçanın Savaşı & 2 & Jön Türkler & 2 \\
\hline Beyaz Gemi & 5 & Vadideki Zambak & 2 & Karabibik & 2 \\
\hline Sherlock Holmes-4 & 5 & Böğürtlen Kışı & 2 & Karanlık Lise & 2 \\
\hline Sherlock Holmes-5 & 5 & Patasana & 2 & Mai ve Siyah & 2 \\
\hline Sherlock Holmes-6 & 5 & Doğu Ekspresinde Cinayet & 2 & Melankolik Aşk & 2 \\
\hline Kavgam & 4 & Hayvan Çiftliği & 2 & Küçük Prens & 2 \\
\hline Aşk & 4 & Trendeki Kız & 2 & Kırlangıç Çı̆̆lı̆̆1 & \\
\hline
\end{tabular}

While 77 participating high school students in the research $\left(\mathrm{n}_{\mathrm{female}}=54 ; \mathrm{n}_{\text {male }}=23\right.$ ) expressed that they did not read any books on the summer holiday, the remaining 189 students expressed that they read 411 different books. It was found that 30 of these students $\left(\mathrm{n}_{\text {female }}=19 ; \mathrm{n}_{\text {male }}=11\right)$ read 1 book, 37 of them (nfemale $\left.=29 ; n_{\text {male }}=8\right)$ read 2 books, 31 of them $\left(n_{\text {female }}=25 ; n_{\text {male }}=6\right)$ read 3 books and 91 of them $\left(n_{\text {female }}=78 ; n_{\text {male }}=13\right)$ read 4 and more books on summer holiday. 314 different books were read by only 1 student. The books with frequency values 2 and above are shown in Table 6. According to this, the books read most by the participating students are 3 books "Eylül" ( $\mathrm{f}=14)$, Sherlock Holmes-1 ( $\mathrm{f}=13)$, Suç ve Ceza $(\mathrm{f}=12)$.

Table 7: The relationship between academic achievement level of biology course and the number of books read on summer holiday

The academic achievement level of biology course (score)

\begin{tabular}{|c|c|c|c|c|c|c|c|c|c|c|c|c|c|}
\hline \multirow[t]{2}{*}{$0-44$} & $\mathrm{f}$ & 1 & 1 & 0 & 1 & 0 & 0 & 0 & 1 & 0 & 0 & 0 & 4 \\
\hline & $\%$ & 25 & 25 & 0 & 25 & 0 & 0 & 0 & 25 & 0 & 0 & 0 & 100 \\
\hline \multirow[t]{2}{*}{$45-54$} & $\mathrm{f}$ & 5 & 0 & 3 & 2 & 3 & 0 & 0 & 0 & 0 & 1 & 1 & 15 \\
\hline & $\%$ & 33.3 & 0 & 20 & 13.3 & 20 & 0 & 0 & 0 & 0 & 6.7 & 6.7 & 100 \\
\hline \multirow[t]{2}{*}{ 55-69 } & $\mathrm{f}$ & 19 & 5 & 7 & 2 & 7 & 3 & 1 & 2 & 0 & 1 & 2 & 49 \\
\hline & $\%$ & 38.8 & 10.2 & 14.3 & 4.1 & 14.3 & 6.1 & 2 & 4.1 & 0 & 2 & 4.1 & 100 \\
\hline \multirow[t]{2}{*}{$70-84$} & $\mathrm{f}$ & 29 & 14 & 18 & 13 & 14 & 10 & 4 & 6 & 5 & 2 & 6 & 121 \\
\hline & $\%$ & 24 & 11.6 & 14.9 & 10.7 & 11.6 & 8.3 & 3.3 & 5 & 4.1 & 1.7 & 5 & 100 \\
\hline \multirow[t]{2}{*}{$85-100$} & $\mathrm{f}$ & 23 & 10 & 9 & 13 & 8 & 4 & 4 & 2 & 3 & 0 & 1 & 77 \\
\hline & $\%$ & 29.9 & 13 & 11.7 & 16.9 & 10.4 & 5.2 & 5.2 & 2.6 & 3.9 & 0 & 1.3 & 100 \\
\hline
\end{tabular}

When Table 7 is examined, the number of books the students with $0-44$ academic achievement level of biology course read on the summer holiday is distributed equally among 0, 1, 3 and 7 books. In other words, among the students with poor academic achievement of biology course, 1 of them $(n=1)$ expressed she/he did not read any books, 1 of them $(n=1)$ expressed that $s /$ he read 1 book, 1 of them $(n=1)$ expressed she/he read 3 
books and remaining $1(\mathrm{n}=1)$ expressed $\mathrm{s} /$ he read 7 books on summer holiday. According to the table 7 , it was determined that $33 \%$ of the students $(n=5)$ having academic achievement level of biology course scores between $45-54$, approximately $39 \%$ of the students $(n=19)$ between $55-69,24 \%$ of the students $(n=29)$ between $70-84$ did not read any books on summer holiday. In addition, it was determined that approximately $30 \%$ of the students $(n=23)$ having a high achievement level of biology course scores between 85-100 did not read any books during the holiday. This finding obtained shows that the majority of the students having low (0-44 scores), middle (45-84 scores) or high (85-100 scores) academic achievement of biology course did not read any books on holiday.

Table 8: Opinions of participating students on the benefits of reading books

\begin{tabular}{llll}
\hline Category & f & Category & f \\
\hline Cognitive Skills & $\mathbf{2 1 6}$ & Personal Development & $\mathbf{7 2}$ \\
\hline Improves the ability to understand & 51 & Improves imagination & 29 \\
\hline Increases exam achievement & 43 & Supports personal development & 15 \\
\hline Improves thinking skills & 40 & Improves the point of view & 20 \\
\hline Increases knowledge & 25 & Provides character improvement & 3 \\
\hline Increases interpreting skills & 18 & A nice hobby to make use of time & 3 \\
\hline Increases general knowledge & 11 & Helps learn from mistakes in life & 2 \\
\hline Relaxes the mind & 10 & Language Skills & $\mathbf{4 2}$ \\
\hline Accelerates the function of the mind & 6 & Accelerates reading & 36 \\
\hline Helps focus & 4 & Gives the habit of reading & 5 \\
\hline Improves consciousness & 4 & Improves writing skills & 1 \\
\hline Gives the skill of speedy decision making & 2 & Affective Skills & $\mathbf{2 2}$ \\
\hline Increases the ability to reason & 2 & Feeds the soul & 8 \\
\hline Communication Skills & $\mathbf{1 6 7}$ & Increases self-confidence & 6 \\
\hline Enriches vocabulary & 66 & Gives the ability to empathize & 5 \\
\hline Improves the ability to speak and address & 50 & Gives happiness & 2 \\
\hline Improves diction & 23 & Increases sensitivity & 1 \\
\hline Improves self-expression skills & 15 & Guide & $\mathbf{3}$ \\
\hline Increases communication skills & 7 & Gives direction to the future & 2 \\
\hline Increases the capability of convincing & 3 & Provides new discoveries & 1 \\
\hline Helps socialize & 3 & & \\
\hline
\end{tabular}

Table 8 shows that 266 participating high school students in the research mentioned 35 different benefits of reading books. The students expressed views on reading books improves cognitive skills ( $\mathrm{f}=216)$, communication skills ( $\mathrm{f}=167)$, personal improvement $(\mathrm{f}=72)$, language skills $(\mathrm{f}=42)$, affective skills $(\mathrm{f}=22)$ and reading books guides the person $(\mathrm{f}=3)$. Thus, they expressed the benefits of reading 522 times and the frequency and percentage values of these metaphors are given in Table 9.

The metaphors the high school students produced on reading books were evaluated and analyzed, the metaphors were categorized according to the relationships among them and their closeness according to their meanings and these categories are given in Table 9. 
Table 9: The metaphors produced on reading books according to their cognitive categories

\begin{tabular}{|c|c|c|c|c|c|c|c|c|c|}
\hline Categories & $\mathrm{f}$ & $\%$ & Metaphors & $\begin{array}{c}\text { Met. } \\
\text { f }\end{array}$ & Categories & $\mathrm{f}$ & $\%$ & Metaphors & $\begin{array}{c}\text { Met. } \\
\text { f }\end{array}$ \\
\hline \multirow{8}{*}{ Life } & \multirow{8}{*}{30} & \multirow{8}{*}{11.9} & Life & 16 & \multirow{4}{*}{ Knowledge } & \multirow{4}{*}{14} & \multirow{4}{*}{5.5} & To be informed & 7 \\
\hline & & & Understanding life & 6 & & & & Learning & 4 \\
\hline & & & Way of life & 2 & & & & Source of knowledge & 2 \\
\hline & & & Source of life & 2 & & & & $\begin{array}{l}\text { The most beautiful } \\
\text { science }\end{array}$ & 1 \\
\hline & & & \multirow{2}{*}{$\begin{array}{l}\text { A new point of } \\
\text { view towards life }\end{array}$} & \multirow{2}{*}{2} & \multirow{2}{*}{ Dream } & \multirow{2}{*}{11} & \multirow{2}{*}{4.3} & Fantasy world & 6 \\
\hline & & & & & & & & Imagination & 5 \\
\hline & & & A part of life & 1 & \multirow{5}{*}{ Heart } & \multirow{5}{*}{11} & \multirow{5}{*}{4.3} & Friend & 6 \\
\hline & & & Philosophy of life & 1 & & & & Friend & 2 \\
\hline \multirow{3}{*}{ Comfort } & \multirow{3}{*}{30} & \multirow{3}{*}{11.9} & Peace & 12 & & & & Love & 1 \\
\hline & & & Resting & 10 & & & & Spirit & 1 \\
\hline & & & Happiness & 8 & & & & Passion & 1 \\
\hline \multirow{3}{*}{ Time } & \multirow{3}{*}{29} & \multirow{3}{*}{11.5} & Waste of time & 11 & \multirow{2}{*}{ Torment } & \multirow{2}{*}{7} & \multirow{2}{*}{2.1} & Torture & 4 \\
\hline & & & Free time activity & 10 & & & & Boredom & 3 \\
\hline & & & Good time & 8 & & & & Guide & 2 \\
\hline \multirow{6}{*}{ Adventure } & & & New worlds & 12 & & & & Road & 1 \\
\hline & & & Freedom & 4 & & & & Mirror & 1 \\
\hline & & & New ideas & 2 & & & & Compass & 1 \\
\hline & 22 & 8.7 & Richness & 2 & Horizon & 8 & 3.2 & Leader & 1 \\
\hline & & & Travel & 1 & & & & Light & 1 \\
\hline & & & $\begin{array}{l}\text { Learning new } \\
\text { stories }\end{array}$ & 1 & & & & Direction & 1 \\
\hline & & & Pleasure & 9 & & & & Hope & 2 \\
\hline & & & Excitement & 3 & Future & 5 & 2 & $\begin{array}{l}\text { The biggest present for } \\
\text { my future }\end{array}$ & 1 \\
\hline Joy & 20 & 7.9 & Fun & 6 & & & & The door to the future & 1 \\
\hline & & & Curiosity & 1 & & & & Stairs to my goal & 1 \\
\hline & & & Beauty & 1 & & & & Bread & 1 \\
\hline & & & Meaninglessness & 12 & & & & Water & 1 \\
\hline Value & 19 & 7.5 & Importance & 6 & Vitality & 5 & 2 & Oxygen Tank & 1 \\
\hline & & & Biological catalyzer & 1 & & & & Breathing & 1 \\
\hline & & & Improving oneself & 13 & & & & Necessity & 1 \\
\hline & & & Good diction & 3 & & & & An ordinary habit & 2 \\
\hline $\begin{array}{l}\text { Personal } \\
\text { improvement }\end{array}$ & 21 & 8.3 & Expressing oneself & 2 & & & 24 & A nice habit & 1 \\
\hline & & & Vocabulary & 1 & Habit & 6 & 2.4 & My favorite habit & 1 \\
\hline & & & A noble behavior & 2 & & & & Addiction & 1 \\
\hline & & & Success & 9 & & & & Ivy & 1 \\
\hline & & & $\begin{array}{l}\text { Understanding } \\
\text { what one reads }\end{array}$ & 1 & & & & & \\
\hline Gain/skill & 14 & 5.5 & $\begin{array}{l}\text { Solving the } \\
\text { questions faster }\end{array}$ & 1 & & & & & \\
\hline & & & $\begin{array}{l}\text { Understanding } \\
\text { history }\end{array}$ & 1 & & & & & \\
\hline & & & Consideration & 1 & & & & & \\
\hline & & & Brainstorming & 1 & & & & & \\
\hline
\end{tabular}

When Table 9 is examined it is seen that the metaphors which have the frequency values of 3 and more are: life ( $f=16)$, self-improvement $(f=13)$, peace $(f=12)$, meaningless $(f=12)$, new worlds $(\mathrm{f}=12)$, waste of time $(\mathrm{f}=11)$, free time activity $(\mathrm{f}=10)$, resting $(\mathrm{f}=10)$, pleasure $(f=9)$, success $(f=9)$, nice time $(f=8)$, happiness $(f=8)$, to be informed $(f=7)$, importance $(f=6)$, 
friend $(\mathrm{f}=6)$, understanding life $(\mathrm{f}=6)$, fantasy world $(\mathrm{f}=6)$, fun $(\mathrm{f}=6)$, imagination $(\mathrm{f}=6)$, freedom $(\mathrm{f}=4)$, torture $(\mathrm{f}=4)$, learning $(\mathrm{f}=4)$, nice diction $(\mathrm{f}=3)$, boredom $(\mathrm{f}=3)$ and excitement $(\mathrm{f}=3)$. 11 metaphors were produced twice, 35 metaphors were produced once. 252 metaphors in total were classified as 16 categories. It is seen that life $(\mathrm{f}=30)$ and comfort categories have the highest frequencies. Life $(\mathrm{f}=16)$, understanding life $(\mathrm{f}=6)$, lifestyle $(\mathrm{f}=2)$, source of life $(\mathrm{f}=2)$, a new point of view in life $(\mathrm{f}=2)$, a part of life $(\mathrm{f}=1)$, philosophy of life $(\mathrm{f}=1)$ metaphors take place in "life" category. The high school students linked reading to life with these metaphors. Some opinions of the students in this category are as below:

"Reading means life to me because reading has become all my life." (S2014)

"Reading means a new point of view to life because it broadens our horizons." (S191)

Peace $(\mathrm{f}=12)$, resting $(\mathrm{f}=10)$, happiness $(\mathrm{f}=8)$ metaphors take place in "comfort" category. They expressed that reading relaxes the individual. A student's opinion in this category is as below: "Reading means relaxing to me because it makes me forget the challenges in real life even for a moment."

Waste of time ( $\mathrm{f}=11)$, nice time $(\mathrm{f}=8)$ metaphors are gathered in the "time" category. The metaphors in this category reveal the students' point of view to reading clearly. Opinions of some of the students are as such:

"Reading means having a good time to me because it takes one to other worlds." (S130)

"Reading means a waste of time to me because doing tests is more important." (S52)

Frequently produced metaphors in the "adventure" category are; new worlds $(\mathrm{f}=12)$ and freedom $(\mathrm{f}=4)$. With these metaphors, students expressed that they officially experience new adventures. In this content, S183 explained his/her opinion saying:

"Reading means entering new worlds for me. Because every book is a new world."

The most frequently produced metaphors in the "joy" category are pleasure $(\mathrm{f}=9)$ and fun $(f=6)$. With the metaphors in this category, the students expressed that they have fun and feel happy when reading. S190 expressed his/her thought as "Reading means fun to me because I both have a good time and learn by losing myself in other worlds when reading." "Meaninglessness" ( $\mathrm{f}=12$ ), "importance" ( $\mathrm{f}=6$ ) and "biological catalyzer" metaphors take place in the "value" category. The students valued reading in their own ways with the metaphors in this category. The biological catalyzer metaphor produced by only 1 student is quite meaningful for this research. The fact that the student likened reading to biological catalyzer is valuable for this research which studied the relationship between reading habits and academic achievement of the biology course. Biological catalyzer 
means something necessary and accelerates the formation of a biochemical process. With this metaphor s/he attributed big value and expressed that reading is indispensable for new formations and changes in life. Opinions of some students in the "value" category are as such:

"Reading means meaninglessness to me because it has no meaning, it doesn't contribute to me." (S112)

"Reading means biological catalyzer to me because it accelerates in every way from thinking to decision making." (S89)

"Self-improvement" ( $\mathrm{f}=13)$, good diction $(\mathrm{f}=3)$, self-expression $(\mathrm{f}=2)$, a noble behaviour $(\mathrm{f}=2)$, vocabulary $(\mathrm{f}=1)$ metaphors take place in "self-improvement" category. The students expressed that reading is very important for self-improvement with this category. Opinions of some students in this category are as such:

"Reading means self-improvement to me because I find pieces from myself in books and self-criticize." (S180)

"Reading means a noble behaviour to me because going out to other worlds and thinking about a lot more important subjects are of the best things to do for me." (S181)

"Success" is the most frequently produced metaphor in the "gain/skill" category. With the metaphors in this category, the students expressed that reading gives skills such as understanding, interpreting, solving questions rapidly and achieving. Opinions of some students in this category are as such:

"Reading means brainstorming to me. Because it helps me think." (S247)

"Reading means solving questions rapidly to me because it increases my reading speed." (S84)

Being informed $(f=7)$, learning $(f=4)$, source of knowledge $(f=2)$, the best science $(\mathrm{f}=1)$ metaphors take place in the "knowledge" category. Some of the participating students' related reading to knowledge and one of the students described it as a discipline saying the best science. The student opinion in this category is as such:

"Reading means being informed to me because books inform people a lot." (S167)

Imagination ( $\mathrm{f}=5)$, dream world $(\mathrm{f}=6)$ metaphors are gathered in the "dream" category. 11 students in total linked reading to dreams. 1 student opinion in this category is as such: 
"Reading means my dream world to me because I find myself there and I relate to the characters." (S111)

Friend $(f=6)$, pal $(f=2)$, love $(f=1)$, heart $(f=1)$ and passion $(f=1)$ metaphors take place in "heart" category. With these metaphors, 11 students in total attributed spiritual value to reading and linked it to heart worlds. S178 explained his/her opinion in this category as such: "Reading means friend to me because I quell my troubles, worries, and loneliness with it."

"Torment" category is the only category with only negative metaphors. In this content torture $(\mathrm{f}=4)$, boredom $(\mathrm{f}=3)$ metaphors take place, the students expressed that they find reading tormenting. Opinions of some students in this category are as such:

\section{"Reading means Chinese torture to me because I don't like reading." (S37)}

"Reading means boredom to me because I don't like it."(S249)

8 students expressed guiding, enlightening and leading benefits of reading in the "horizon" category. In this category, S241 explained his/her opinion as such: "Reading means guide to me because it guides my life."

Hope $(f=2)$, the biggest present for my future $(f=1)$, door opening to the future $(f=1)$, stairs to my goal $(\mathrm{f}=1)$ metaphors are gathered in the "future" category. The future benefits of reading are mentioned with these metaphors. In the content of this category, S137 expressed his/her metaphor and explanation as such: "Reading means the biggest present for my future because even one book can change life entirely."

Bread $(\mathrm{f}=1)$, water $(\mathrm{f}=1)$, oxygen tank $(\mathrm{f}=1)$, breathing $(\mathrm{f}=1)$ and necessity $(\mathrm{f}=1)$ metaphors take place in "vitality" category. Reading has vital importance for the students who produced these metaphors. In this category, S62 wanted to emphasize to what degree reading is important for the continuity of life by saying "Reading means bread to me because it is indispensable."

An ordinary habit $(\mathrm{f}=2)$, a nice habit $(\mathrm{f}=2)$, my favourite habit $(\mathrm{f}=2)$, addiction $(\mathrm{f}=2)$ and ivy $(f=2)$ metaphors are gathered in the "habit" category. With the metaphors in this category, it was emphasized that reading is a matter of habit. S107 expressed his/her opinion with the explanation "Reading means habit to me because it is addicting."

\section{Result}

From the findings of the study, it is seen that $19.9 \%(n=53)$ out of 266 students who study in the final year of various high schools and have taken biology course before in Kars province almost have no habit of reading and $21 \%(n=56)$ of them don't have libraries in their homes as of the year of 2018.

$86 \%(n=227)$ of the participating students expressed that they read novels/stories, $6.7(n=18)$ of them expressed that they read science books. From this result, it can be 
inferred that students need more motivation to read science books in the name of the improvement of scientific literacy.

With this research it is seen that there is a meaningful relationship between school type and the number of monthly read books on average, time spared for reading daily and book type; also gender and availability of library in home and nonstop reading time at a time.

93\% ( $\mathrm{n}=247)$ of the participating students' academic achievement scores of biology course are 55 and above; $74.4 \%(\mathrm{n}=198)$ of them are 70 and above. This situation is quite pleasing for our country of which school report is quite bad in general sense in biology subjects.

It is determined that there is a meaningful relationship between gender and the number of monthly read books on average, the majority of the female students read 2 books monthly, however, the majority of the male students don't read at all. A meaningful relationship is seen between the gender variable and time spared for reading daily. It is determined that the majority of the participating male students don't spare any time for reading daily, on the other hand, the majority of the female students spare 1-2 hours for reading daily. A minor difference was observed between genders in terms of book type, while $15 \%$ of the male students read science books this rate is seen as $4 \%$ for the females. As for in general, it was concluded that the participating students read mostly novels/stories.

It was concluded that only $22 \%$ of 266 participating students $(n=59)$ read 5 and more books during the summer holiday. However, the fact that 47 of these 59 students have achievement scores of the biology course above 70 and above can be accepted as an indicator that there might be a relationship between reading and academic achievement of the biology course.

The data of this study shows that there is a parallel relationship between the academic achievement of biology courses and reading habits. So much so that; it is seen that as academic achievement score of biology course increased, the number of books read monthly and time spared for reading daily increased. For instance, it is understood that $93.3 \%$ of the students who have an academic achievement score of biology course 70 and more which means almost all of them spare 3 hours or more for reading. This result shows that all of the students in the sample who read for more than 3 hours a day are successful in biology course which means reading increases biology course achievement. It is seen that of the 266 students who participated in the study only $23 \%$ of them $(n=60)$ read for 3 or more hours at a time; $49,6 \%$ of them read for 1 hour or less at a time. These two data reveal that time spared for reading at a time is very little, the students who can be considered good readers remain in the minority.

It was determined that approximately $36.8 \%$ of the students participating in the research ( $n=98)$ read $1-3$ books; $34.2 \%$ of them $(n=91)$ read 4 and more books during the summer holiday. In addition, it was determined that $33 \%$ of the students with academic achievement level of biology course between $45-54(n=5)$, approximately $39 \%$ of the students between $55-69(n=19), 24 \%$ of the students between $70-84(n=29), 30 \%$ of the 
students between 85-100 $(\mathrm{n}=23)$ did not read any books during the holiday. This result shows that approximately $29 \%$ of the participating students in total $(n=77)$, in other words, 1 in 3 students did not read any books during the summer holiday.

On the other hand, it is seen that only $41.7 \%$ of the participating students in this study ( $n=111)$ read for 1 hour or less daily. This result shows that more than half of the participants did not read much, all the campaigns and efforts for reading did not reach their goals.

In general, although the fact that the students who read relatively more books are of the students who are successful in biology course shows that there is a parallel relationship between the habit of reading books and academic achievement of biology course, it is determined that students with high level of biology course do not read enough books.

It was found that 266 participating students read 411 different books during the summer holiday of 2018 and the most preferred book $(\mathrm{f}=14)$ was the book called September".

Within the scope of the study, the benefits of reading were asked to the students as open-ended. The answers obtained were analyzed, put in order according to their frequency values and categorized by the researchers. Some of the opinions in the cognitive skills category $(\mathrm{f}=216)$ are as such: Increases the capacity to understand, increases exam achievement, improves thinking skills, increases knowledge, improves interpreting skills. Some of the opinions in the communication skills category $(\mathrm{f}=167)$ are as such: Enriches vocabulary, improves speaking and addressing ability, improves diction, improves self-expression skills, improves communication skills. Some of the opinions in the personal development category $(\mathrm{f}=72)$ are as such: Improves imagination, supports self-improvement, improves point of view, broadens the horizon, enables character development. Some of the opinions in the language skills category $(\mathrm{f}=42)$ are as such: Accelerates reading, gives the habit of reading, improves writing skills. Some of the opinions in affective skills $(\mathrm{f}=22)$ are as such: Relaxes the mind, increases self-confidence, feeds the soul, heals, gives happiness. Some of the opinions in the guidance category $(\mathrm{f}=3)$ are as such: Enables learning from lessons in life, gives direction to the future, shows the way, helps make new discoveries.

In the part in which phenomenological approach was used, the participating students were asked a question as "Reading is like......for me because........" and they were asked to produce metaphors for reading and justify that. The metaphors produced were evaluated by the researchers, they were gathered in 16 categories considering their common features and it was found that 252 metaphors were produced 72 of them being different from one another. The metaphor with an interdisciplinary function acts as a translator between facts (Morgan, 1998). Thus, in the question that metaphor is produced by the phenomenological approach, students' subconscious, thoughts, and perceptions about reading are clearly revealed. Positive negative, whether they like it or not, whether they care or not were determined clearly.

$11.9 \%$ of the participants linked reading to life itself; $11.9 \%$ of them expressed that reading is a relaxing activity; $8.7 \%$ of them expressed that reading is new adventures. 
Approximately $8 \%$ of the participants emphasized the enjoyable side of reading; 8.3 of them expressed that it is self-improving, $5.5 \%$ of them expressed that it gives a lot of skills and success; $5.5 \%$ of them pointed the informative side, $4.3 \%$ of them pointed the imagination improving side, $3.2 \%$ of them pointed the horizon-broadening side; $2 \%$ stated that it means future, $2 \%$ of them stated that it means it is vital as bread, water and breath. A group of $2.4 \%$ mentioned that reading is a matter of habit. 244 students in total glorified reading, emphasized its importance and attributed value to it.

On the other hand, 28 students put their negative perceptions, feelings, and thoughts forward on reading. In this category, 11 students stated that reading means a waste of time; 10 students stated that it does not matter much; 4 students stated it means torture, 3 students stated it means boredom. Thus $10.5 \%$ of the participants in total expressed that they do not like reading, it does not matter to them and they get bored when reading.

\section{Argument}

According to PISA 2015 reading skills field results, female students are more successful than male students on the basis of all countries. In the same report, while the reading skills score of the female students in Turkey is 442, the score of male students is 414 . Majority of the studies conducted for determining reading habits (Ac1yan,2008; Arslan, Çelik and Çelik,2009; Davarc1,2013; Güney et al., 2014; Akın,2016) show that female students read more books than male students, they have a more positive attitude to reading, they buy more books, they like reading more and they have the habit of reading. Torppa, Eklund, Sulkunen, Niemi, and Ahonen (2018) stated that males have less pleasure in reading compared to females, they are less interested in it and they are poor readers depending on the findings of researches conducted internationally. Similarly, in this research, it was determined that female students read more than male students daily and monthly, that they spare more time for reading nonstop at a time.

Gallik (1999) concluded that there is a positive relationship between the academic achievement of university students and their extracurricular reading habits, Sallabaş (2008) concluded that there is a positive relationship between academic achievement and reading comprehension skills; Güney et al. (2014) concluded that there is a positive relationship between academic achievement and the number of books read; Applegate and Applegate (2004) concluded that the majority of individuals who enjoy reading have a high level of achievement. There are also some literature records that reading increases academic achievement in different courses. Güngör (2009) concluded that reading increases the academic achievements of 5th-grade students in the Turkish course; Akın (2016) concluded that there is a positive relationship between the academic achievement score of the Turkish course and reading habit. Tatar and Soylu (2006) concluded that the students who have difficulties in reading-comprehension have low achievement in the Maths course. Data of this study also show that there is a positive relationship between the academic achievements of biology course and reading habit, as academic 
achievement score of biology course rises the number of books read monthly and time spared for reading daily increases.

In the study Gül (2013) conducted with high school students, the students stated that reading increases achievement in paragraph questions, improves their diction, improves vocabulary, intelligence, ability to do tests and imagination. Within the scope of this research participating high school students stated that reading increases comprehension, exam achievement; enriches imagination, improves the ability to interpret, speaking, diction and addressing; provides character and personality development; improves imagination, perspective, and writing skills; relaxes the mind and increases self-confidence; feeds the soul and gives happiness; shows the way and provides new discoveries.

In the study Davarc1 (2013) conducted in Adana central districts with 8th-grade students; it was concluded that only $29.8 \%$ of the students enjoy reading and $42.9 \%$ of them do not have libraries in their homes. This study shows that nearly $19.92 \%$ of the students have never read books and $21 \%$ of them do not have libraries as of the year of 2018.

In the study Göktaş and Gürbüztürk (2014) conducted with high school students, it was determined that $52.3 \%$ of the students read once a week, $30 \%$ of them read once a month. Aksaçlioğlu and Yilmaz (2007) determined that 56.8\% of the students who participated in the study they conducted in Çankaya Primary School read 2 books and more a month; $48.6 \%$ of the students enjoy reading. It was concluded that $52.6 \%$ of the high school students participating in this study read 2 books and more a month.

Aclyan (2008) examined the relationship between reading habit and achievement in school, $57.2 \%$ of the participating students in the research stated that reading increases their achievement. Other students participating in this research stated that reading means comprehension, solving questions rapidly, understanding history and being successful in the metaphors they produced.

In the research Yilmaz (2012) conducted with 8th-grade students, he stated that there are not any students among the students who got a letter of appreciation that do not like reading. The same study showed the relationship between attitude toward reading and education success and revealed that the group with the lowest scores consists of the students who do not enjoy reading. This fact indicates that the students who enjoy reading ate the ones with the highest achievement in school. In this study, the fact that the students who read more books were among the students who were successful in the biology course showed that there was a positive relationship between reading habits and academic achievement. It was understood that almost $93.3 \%$ which means almost all of them who have the academic achievement score of biology course 70 and above are the students who spare 3 and more hours for reading daily.

Aclyan (2008) stated that reading habit is poor in our society. This research revealed that there are students who do not have libraries in their homes, the rate of reading science books is quite low, nearly half of the participants read a maximum of 1 hour or less at a time. 
PISA 2015 showed that science schools are the most successful, vocational and technical schools are the least successful in both reading skills and science literacy scores. In this research, no meaningful relationship was encountered between school type and the students' monthly and daily reading amount.

According to PISA 2015, the rate of the students with high proficiency in terms of science literacy is $0.3 \%$; The rate of the students with high proficiency in terms of reading skills is $0.06 \%$ in Turkey. Similarly, according to data of this research, the rate of the students who read 4 and more books a month is $8.3 \%$; The rate of the students who spare 3-4 hours for reading daily is 5.6\%; The rate of the students who read for more than 4 hours at a time is $14.7 \%$; the rate of reading science books is 6.8 . All these data corroborate one another and when evaluated together the sad picture in this matter is seen clearly. In Bektaş, Okur and Karadağ (2014) primary school and secondary school students produced knowledge, source of knowledge, friend, life, water, compass metaphors related to "book" notion; in Özden (2017) secondary school students produced friend, pal, love, life, mirror, light, lantern, heart, door, compass, source of knowledge, mine of information, dream, dream world, water, adventure, freedom, living, richness, guide, therapy, adventure, source of joy, happiness metaphors related to "book" notion again; in Akbulut, Özdemir, and Cıvğın (2017) secondary school students produced tool to learn, source of knowledge, door opening to other worlds, friend, a boring tool related to "book" notion and source of happiness, necessity, way to learn, too to improve, a boring activity metaphors related to "reading". All these metaphors produced related to this subject show similarity to the findings of this research.

Çalışkan (2009) compiled the metaphors Cemil Meriç used related to "book". Meriç used "grain" metaphor which is a physical necessity related to "book" notion, the high school students participating in this study used "bread, water, oxygen tank, breath" metaphors which point to the physical necessities; Meriç used "door" and "letter sent to the future" metaphors, the participants in this study used "door opening to the future" metaphor; Meriç used "light" metaphor, the participants in this study used "light" metaphor. The metaphors show similarity in this respect.

\section{Suggestions}

This research was conducted by considering the first three years of biology course averages of the students in the fourth grade of secondary education as an indicator of their academic achievement and the effect of reading habits on the academic achievement of biology course was examined. In order to contribute to the literature and reveal the truth of Turkey in this matter reading habits should be examined in different universes and samples and the relationship between different academic achievements. Some suggestions were made below in this respect.

1. The effect of reading habit on high school entrance exam in the studies to be conducted on secondary school graduates; 
2. The effect of reading habit on their four-year averages of biology course in the studies to be conducted on secondary school graduates;

3. The effect of reading habit on the graduation scores by accepting their general graduation scores as the criterion of their four-year academic achievement;

4. Correlation between the related field scores of university entrance exam and reading habits of university students;

5. The relationship between reading habits and graduation scores of university graduates by accepting their graduation scores as the criterion of their four-year academic achievement;

6. Studies in which the correlation between KPSS exam results and reading habits of teacher candidates are examined should be conducted.

\section{Conflict of Interest Statement}

The authors declare that they have no conflict of interest related to the study or preparation of the manuscript.

\section{About the Authors \\ Arzu Önel has been working as an Associated Professor Doctor at Department of Biology Education Faculty of Education at Kafkas University in Turkey. Her interest areas are biology, biology education, evolution, human anatomy and physiology, and ecology awareness.}

Şule Furat Durdukoca has been working as an Associated Professor Doctor at Department of Special Educational Faculty of Education at Kafkas University in Turkey. Her interest areas are teaching practices, learning approaches, learning difficulties, and metacognitive awareness.

\section{References}

Acryan, A. A. (2008). The relationship between reading habits and academic achievement levels of secondary school students (Postgraduate Thesis). Yeditepe University, Social Sciences Institute, İstanbul.

Adalı, O. (2010). Interactive and critical reading techniques. İstanbul: Toroslu Edition.

Akbulut, S., Özdemir, E. E. \& Cıvğın, H. (2017). Metaphoric Perceptions of Secondary School Students in Book and Reading. Turkish Journal of Primary Education, 2, 30 43.

Akın, E. (2016). Examination of the relationship between reading habits and writing attitudes and academic achievement of the Turkish course. Akademik Bakış Dergisi, 54.

Aksaçlığlu, A. G., \& Yılmaz, B. (2007). The effect of students' watching TV and using a computer on their reading habits. Türk Kütüphaneciliği, 21(1), 3-28.

Aktaş, Ş. \& Gündüz O. (2005). Written and oral expression. Ankara: Akçağ Edition. 
Applegate, A. J., \& Applegate, M. D. (2004). The peter effect: Reading habits and attitudes of preservice teachers. The Reading Teacher, 57(6), 554-563.

Arslan, Y., Çelik, Z., \& Çelik. E. (2009). Determining the attitudes of university students towards reading habits. Pamukkale Üniversitesi Ĕ̆gitim Fakültesi Dergisi, 26(26), 113124.

Baş, T. \& Akturan, U. (2013). Qualitative research methods. Ankara: Seçkin Edition

Batur, Z. \& Bek, H. G. H. (2010). A study on the reading habits of teacher candidates: Uşak Education Faculty sample. Uşak University Social Sciences Journal, 3(1), 32-49.

Bektaş, M., Okur, A. \& Karadağ, B. (2014). Book as Metaphorical Perception of Primary and Secondary School Students. Türk Kütüphaneciliği, 28(2), 154-168.

Büyüköztürk, Ş. (2007). Manual of data analysis for social sciences. Ankara: Pegem Edition.

Cunnington, A. E., \& Stanovich, K. E. (2003). Reading can make you smarter! Principal, 83(2), 32-39.

Davarc1, N. (2013). Evaluating the relationship between reading habits and using computerinternet of primary school 8th graders (Postgraduate Thesis). Çukurova University Social Sciences Institute Primary School Department, Adana.

Devrimci, H. (1993). Examination of reading habits of primary school 5th-grade kids. Hacettepe University Health Sciences Institute, Ankara.

Gallik, J. D. (1999). Do They Read for Pleasure? Recreational Reading Habits of College Students. Journal of Adolescent $\mathcal{E}$ Adult Literacy, 42(6), 480-488.

Göktaş, Ö. \& Gürbüztürk, O. (2014). The effect of reading comprehension skills on academic achievement of primary school second level maths course. International Journal of Curriculum and Instructional Studies, 2(4), 52-66.

Gül, M. (2013). Reading purposes and strategies of secondary school 6-7-8 grade students. Erciyes University Education Sciences Institute Turkish Department Turkish Education Science, Kayseri.

Güney, N., Aytan, T., Kaygana, M., \& Şahin, E. Y. (2014). An evaluation of the number of books read and academic achievements of ninth-grade students. Süleyman Demirel University Social Sciences Institute Journal, (19), 151-164.

Güngör, E. (2009). Examining the relationship between reading habits and academic achievements of the Turkish course of primary school 5.grade students (Post graduation Thesis). Çukurova University Social Sciences Institute Primary School Teaching Department, Ankara.

Issa, A. O., Aliyu, M. B., Akangbe, R. B., \& Adedeji, A. F. (2012). Reading interests and habits of the federal polytechnic, OFFA, Students. International Journal of Learning and Development, 2(1), 470-486.

Karasar, N. (2009). Scientific research method. Ankara: Nobel Edition.

Keçik, İ. (2001). The act of listening. Verbal and written expression in Turkish. Eskişehir: Anadolu University Faculty of Open University Edition, 95-108.

Marks, G., McMillan, J., \& Hilman, K. (2001). Tertiary Entrance Performance: The Role of Student Background and School Factors. Camberwell, Victoria: Australian Council for Educational Research. 
Miles, M. B., Huberman, A. M. (1994). Qualitative data analysis: An expanded sourcebook (2nd Edition). California: SAGE Publications.

Ministry of National Education PISA 2015 International Report.

Morgan, G. (1998). Metaphor in Management and Organization Theories. İstanbul: MESS Edition.

Özdemir, E. (1990). Art of reading. İstanbul: Remzi Bookstore.

Özden, M. (2017). Metaphoric Perceptions of Secondary School Students on Book and Library. Trakya University Literature Faculty Journal, 7 (14), 1-34.

Reed, D. K., Petscher, Y., \& Truckenmiller, A. J. (2017). The contribution of general reading ability to science achievement. Reading Research Quarterly, 52(2), 253-266.

Sallabaş, M. E. (2008). The relationship between the attitudes towards reading and reading comprehension skills of 8 . grade students. Inönü University Education Faculty Journal, 9(16), 141-155.

Tatar, E. \& Soylu, Y. (2006). A study on determining the effect of success in comprehension on the achievement of maths. Kastamonu Education Journal, 14(2), 503-508.

The Programme for International Student Assessment (PISA-2015). National Report. http://pisa.meb.gov.tr/wp-content/uploads/2014/11/PISA2015 UlusalRapor.pdf.

Torppa, M., Eklund, K., Sulkunen, S., Niemi, P., \& Ahonen, T. (2018). Why do boys and girls perform differently on PISA Reading in Finland? The effects of reading fluency, achievement behavior, leisure reading and homework activity. Journal of Research in Reading, 41(1), 122-139.

Yild1z, M. (2013). The role of reading motivation, reading fluently and reading comprehension in fifth-grade students. Turkish Studies, 8(4), 1461-1478.

Yilmaz, B. (2012). The effect of reading habit on success in school: A study on Ankara Keçiören Atapark Primary School Students. Prof. Dr. K. Gülbün Baydur'a Armağan, 209-218.

Yilmaz, C. \& Okur, A. (2010). A matter ignored in reading activities in primary schools: vocabulary teaching. TÜBAR-XXVII, 753-773. 

to copy, distribute, transmit or adapt the article content, providing a proper, prominent and unambiguous attribution to the authors in a manner that makes clear that the materials are being reused under permission of a Creative Commons License. Views, opinions and conclusions expressed in this research article are views, opinions and conclusions of the author(s). Open Access Publishing Group and European Journal of Education Studies shall not be responsible or answerable for any loss, damage or liability caused in relation to/arising out of conflicts of interest, copyright violations and inappropriate or inaccurate use of any kind content related or integrated into the research work. All the published works are meeting the Open Access Publishing requirements and can be freely accessed, shared, modified, distributed and used in educational, commercial and non-commercial purposes under a Creative Commons Attribution 4.0 International License (CC BY 4.0). 